\title{
A Study on Weed Flora and Importance Value Index of Weeds in Wheat Crop
}

\author{
Firat Pala (Corresponding author) \\ Department of Plant Protection, Agriculture Faculty, Siirt University, Siirt, Turkey \\ E-mail: firatpala@edu.tr \\ Murat Erman \\ Department of Field Crops, Agriculture Faculty, Siirt University, Siirt, Turkey \\ E-mail: rektor@edu.tr \\ Fatih Cig \\ Department of Field Crops, Agriculture Faculty, Siirt University, Siirt, Turkey \\ E-mail: fatih@edu.tr \\ Halil Dilmen \\ Department of Plant Protection, Agriculture Faculty, Siirt University, Siirt, Turkey \\ E-mail: halildilmen@edu.tr
}

\begin{abstract}
Weeds are an important problem because they reduce the yield and quality of wheat. This study was carried out to determine the phytosociology of weeds in wheat fields of Siirt, Turkey. A square-frame inventory method was used that was randomly released at least four times from 90 different locations between March and May in 2019. A total of 71 weed species belonging to 20 different families, one of which is grass (12 species) and 19 broadleaf (59 species) were identified. Asteraceae (with 15 species) were identified as the predominant family, followed by Poaceae (with 12 species), Brassicaceae and Fabaceae (with 8 species). The highest frequency, density and abundance values were determined Avena sterilis L. (83\%, 11.4 plant $\left.\mathrm{m}^{-2}, 32.8 \%\right)$, Sinapis arvensis L. (81\%, 9.6 plant $\left.\mathrm{m}^{-2}, 41.3 \%\right)$, Ranunculus arvensis $L$. (77\%, 4.3 plant $\left.\mathrm{m}^{-2}, 24.4 \%\right)$, Galium aparine L. $\left(66 \%, 8.2\right.$ plant $\left.\mathrm{m}^{-2}, 12.8 \%\right)$, and Cirsium arvense (L.) Scop. $\left(61 \%, 5.5\right.$ plant $\left.\mathrm{m}^{-2}, 29.0 \%\right)$ species were the maximum. When the above values are calculated relatively, importance value index (IVI) were detected Avena sterilis L. (22.3\%), Sinapis arvensis L. (22.2\%), Papaver rhoeas L. (15.9\%), Cirsium arvense (L.) Scop. (14.1\%), and Galium aparine L. (13.5\%) species were the highest. According to the economic threshold (according to the current literature) Avena sterilis L. and Sinapis arvensis L. were identified as noxious weeds. This research will shed light on the determination of the noxious weeds, economic threshold and environmentally-friendly integrated weed management tactics to be developed in wheat.
\end{abstract}

Keywords: Wheat, Weeds, Frequency, Density, Abundance, Importance value index

DOI: $10.7176 / \mathrm{JSTR} / 6-01-05$

\section{Introduction}

Economic losses caused by weeds are of great importance in agricultural production (Oerke 2006; Zimdahl, 2013). Global warming, soil and agricultural practices (eg tillage, irrigation, and fertilization) have a higher or lower potential to influence the abundance and diversity of weed species in a wheat field (Peters et al., 2014; Travlos et al., 2018).

Predominant weeds prevailing in winter wheat crops were common wild oat (Avena fatua $\mathrm{L}$.), wild oat (Avena sterilis L.), blackgrass (Alopecurus myosuroides Huds.), canarygrass (Phalaris brachystachys Link.), ryegrass (Lolium multiflorum Lam.), wild mustard (Sinapis arvensis L.), devil-on-all-sides (Ranunculus arvensis L.), poppy (Papaver rhoeas L.), chamomile (Anthemis arvensis L.), and vetch (Vicia sativa L.) in the studies carried out in the region (Pala and Mennan, 2017; Pala et al., 2018). Weeds, 
which are a problem in wheat production areas, compete with culture plants for nutrients, water and light, and cause losses of more than $80 \%$ in yield (Cousens and Mortimer, 1995).

As most of the weeds can easily germinate, cover the field quickly and produce seeds under suitable environmental and soil conditions, their management (usually herbicide-based) become inevitable (Spitters, 1989). But before deciding on chemical control, it is necessary to know the economic threshold of weed. The economic threshold can be defined as the weed density at which the cost of herbicide application is equal to the economic benefit of spraying (Cousens et al. 1985). Researchers have tried to produce economic thresholds for control of weeds in cereals (LeBaron et al., 2008).

Once weeds that exceed the economic threshold and need herbicide use, weeds are called the noxious weeds and they are a threat to sustainable crop production (Gbèhounou, 2013). The economic threshold is considered as the weed abundance at which the cost of weed control is equal to the crop yield increase caused by this control. Thus, the control is economically profitable for higher weed abundances (Coble and Mortensen 1992). In the last decades, much research effort was devoted to the proper setting of weed economical thresholds. Economic thresholds were determined for some weed species found in winter wheat. For thistle [Cirsium arvense (L.) Scop.] and couch grass [Elytrigia repens (L.) Nevski] the economic threshold was -0.1 plant $\mathrm{m}^{-2}$ (Häusler et al., 1998), for mustard (Sinapis arvensis L.) it varied between 1.02 and 5.38 plants $\mathrm{m}^{-2}$ (Mennan, 2003), while Boz and Uygur (1997) founded 0.1-0.3. Zanin et al., (1993), who has done the most comprehensive work on this subject stated for steril wild oat [Avena sterilis L. subsp. ludoviciana (Durieu) Nyman] the economic threshold was between 7 and 12 plants $\mathrm{m}^{-2}$ (while Kadioglu et al., 1993 found 3-5), for foxtail "black grass" (Alopecurus myosuroides Huds.) (while Meiner, 2015 found 12) and Italian rye-grass (Lolium multiflorum Lam.) it varied between 25 and 35 plants $\mathrm{m}^{-2}$, while for barren brome (Bromus sterilis L.) the values were just under 40 plants $\mathrm{m}^{-2}$. For sticky willy (Galium aparine L.) the threshold was as low as 2 plants $\mathrm{m}^{-2}$, while for garden vetch (Vicia sativa L.) it was between 5 and 10 plants $\mathrm{m}^{-2}$. For cereals, most authors provide values $40-50$ plant $\mathrm{m}^{-2}$ for unspecified broadleaf weeds and 20-30 plant $\mathrm{m}^{-2}$ for unspecified grass weeds (Beer and Heitefuss 1981, Wahmhoff and Heitefuss 1985, Häusler et al. 1998, Gerowitt and Heitefuss 1990, Zanin et al. 1993) The thresholds of some weeds in other crops are as follows; for red-rooted pigweed (Amaranthus retroflexus L.) the economic threshold was between 0.09 and 0.13 plant $\mathrm{m}^{-2}$ (Vazin, 2012) and for lamb's quarters (Chenopodium album L.) it varied between 4 and 6 plant $\mathrm{m}^{-2}$ in corn (Onofri et al., 1994), also

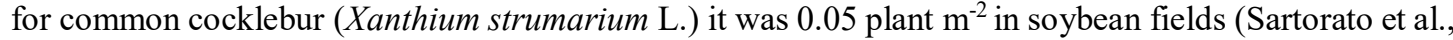
1996) found) so this value was the lowest. Within the same species, the different values of economic threshold result from the different costs and efficacy of herbicides.

Great savings can be obtained by determining thresholds for a particular mixture of weeds. The economic threshold of weeds can be estimated by considering leaf area, weed type, crop and spray cost, level of risk and priorities of the growers (Ali et al., 2012). The use of herbicides in wheat is the only acceptable way for effective weed management in wheat (Ashiq et al., 2006). Recent studies showed that herbicide treatment gave $87-90 \%$ weed control, with a consequent $19-21 \%$ increase in grain yield (Khan et al., 2005). But the applications of herbicides have raised public concern about the possible effects on human health, residues in food and drinking water. Therefore, the determination of noxious weed species must be well known in order to choose effective and correct control methods of weeds

This study based on the information given is aimed to determine the main noxious weed species in Siirt which is the wheat production center of Siirt situated in Turkey's Southeastern Anatolia Region. The findings of this study will contribute to the development of integrated combat strategies that are effective against major weeds in wheat and do not ignore ecology and the environment. 


\section{Material and Methods}

This study was carried out as phytosociological surveys in the wheat fields of Siirt, an agricultural city on the southern slope of Southeastern Taurus Mountains in Turkey in 2019 (Figure 1).

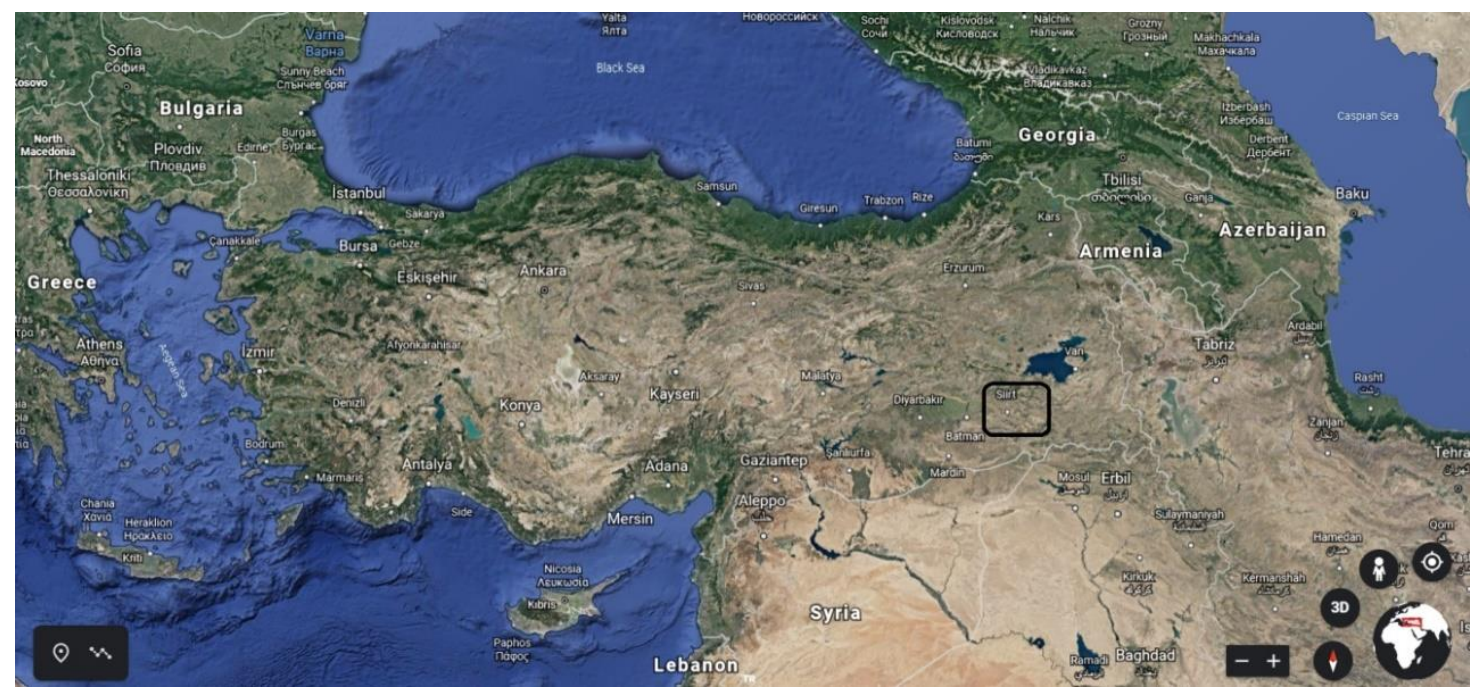

Figure 1. Location of the province of Siirt where survey studies are carried out

There is more rainfall in the winter than summer in Siirt, which has a warm and dry climate in summer. The average annual temperature in Sirt is $16.2^{\circ} \mathrm{C}$, with the warmest month of July at $30.2{ }^{\circ} \mathrm{C}$ and the coldest average of January with $2.9^{\circ} \mathrm{C}$. The average annual rainfall is $767 \mathrm{~mm}$, the greatest amount of precipitation occurs in March with an average of $117 \mathrm{~mm}$, and the driest month is August with $1 \mathrm{~mm}$ of rainfall (MGM, 2019). About 9\% of the territory of Siirt land was classified as I. (9 thousand ha), II. (18 thousand ha) and III. (35 thousand ha) class capability and grain cultivation is carried out on red calcareous soils (DIKA, 2019). Pistachio, vineyard, cereals (wheat and barley), pulse (lentil and chickpea) cultivations are widely used in cultivated land. Kurtalan located on the western side of Siirt has relatively flat and fertile agricultural lands and has become the grain production center of the province. The surveys were carried out in Baykan, Eruh, Kurtalan, Merkez, Sivan, and Tillo districts where wheat production is made in Siirt province. In the province, a proportional distribution was made by taking into account the highest production areas (Table 1).

Table 1. Siirt district wheat fields surveyed and sampling numbers

\begin{tabular}{lccc}
\hline Locations & Wheat field (ha) & Production (t) & Number of samples \\
\hline Baykan & 2.514 & 5.729 & 6 \\
Eruh & 2.537 & 4.540 & 7 \\
Kurtalan & 24.549 & 79.965 & 63 \\
Merkez & 3.124 & 7.911 & 8 \\
Sirvan & 2.091 & 4.105 & 5 \\
Tillo & 194 & 4.44 & 1 \\
\hline \multicolumn{1}{c}{ Total } & $\mathbf{3 5 . 0 0 9}$ & $\mathbf{1 0 2 . 6 9 4}$ & $\mathbf{9 0}$
\end{tabular}

TUIK, 2018

The surveys were carried out during the period when weeds could be easily identified (in March-May). Even though the sampling areas were in the same direction, care was taken to ensure that they were in different locations and directions. At least $3 \mathrm{~km}$ was observed between each observation field. Counts were started at least $10 \mathrm{~m}$ from the fields to eliminate the edge effect. A square metal frame with an area of $1 \mathrm{~m}^{2}$ was randomly placed at least four times on each studied area using the square-inventory method proposed by Odum (1971). Totally 90 wheat fields representing $30 \%$ of the total area were sampled during the surveys. Broadleaf weeds were evaluated as whole plants and grass stems were counted and processed into survey forms. Weeds present in each sampled area were cut close to the soil, packed in 
plastic bags, and taken for identification and quantification. Phytosociological surveys were applied to the studies on the agroecosystem of weed plant populations for wheat (Santos et al., 2016). The following phytosociological parameters were determined: frequency $(\mathrm{F})$, relative frequency (Fr), density (D), relative density (Dr), abundance (A), and relative abundance (Ar) for each one of the fields. The relative indexes were used for calculation of the importance value index (IVI), in percentage. In order to calculate, the following formulas were used by Concenço, (2013).

$\mathrm{F}=$ no. of squares that have the species / total no. of squares obtained

$\mathrm{Fr}=\mathrm{F}$ of the species $* 100 /$ total frequency of the species

$\mathrm{D}=$ total no. of individuals per species / total the area occupied by the squares

$\mathrm{Dr}=\mathrm{D}$ of the species $* 100 /$ total density of the species

$\mathrm{A}=$ total no. of individuals per species / total no. of squares that contain the species

$\mathrm{Ar}=\mathrm{A}$ of the species $* 100 /$ total abundance of the species

$\mathrm{IVI}=\mathrm{Fr}+\mathrm{Dr}+\mathrm{Ar}$

Economic thresholds were identified according to current literature. The identification of species of weeds from each frame was done by comparison, according to the Flora of Turkey (Davis, 1965-1989).

\section{Results}

Since it is known that spraying of grass and broad-leaved weeds were done in the first half of March, observations were made before and after spraying and averaged. Knowing the weed species and their density in Siirt, which is the important cereal production center of the region, can contribute to the robust design and implementation of integrated weed management programs that can lead to an increase in ecological and environmental awareness in the appropriate management against them. In this study, the results obtained for the frequency, density, abundance, importance value index, also economic threshold (taken from studies conducted for the identification of noxious weeds) of weeds were given in Table 2.

Tablo 2. The frequency, density, abundance, importance value index, and economic threshold of weeds detected in wheat fields of Siirt, Turkey

\begin{tabular}{|c|c|c|c|c|c|c|c|c|c|}
\hline Family/Species & Common name & $\mathbf{F}$ & Fr & D & Dr & $\mathbf{A}$ & Ar & IVI & ET \\
\hline \multicolumn{10}{|l|}{ APIACEAE } \\
\hline Turgenia latifolia (L.) Hoffm. & False carrot & 56 & 4.1 & 3.0 & 3.6 & 23.1 & 5.6 & 9.6 & \\
\hline Scandix pecten-veneris $\mathrm{L}$. & Shepherd's-needle & 16 & 1.2 & 0.4 & 0.5 & 3.1 & 0.8 & 1.4 & \\
\hline Daucus carota $\mathrm{L}$. & Queen Anne's lace & 6 & 0.4 & 0.3 & 0.4 & 1.9 & 0.5 & 0.9 & \\
\hline \multicolumn{10}{|l|}{ ARISTOLOCHIACEAE } \\
\hline Aristolochia maurorum L. & Dutchman's pipe & 2 & 0.1 & 0.2 & 0.2 & 0.2 & 0.1 & 0.3 & \\
\hline \multicolumn{10}{|l|}{ ASTERACEAE } \\
\hline Cirsium arvense (L.) Scop. & Thistle & 61 & 4.5 & 5.5 & 6.6 & 29.0 & 7.0 & 14.1 & -0.1 \\
\hline Anthemis arvensis L. & Mayweed chamomile & 47 & 3.4 & 1.2 & 1.4 & 15.9 & 3.9 & 5.6 & \\
\hline Lactuca serriola $\mathrm{L}$. & Prickly lettuce & 39 & 2.8 & 0.8 & 0.9 & 20.1 & 4.9 & 6.1 & \\
\hline Tragopogon latifolius Boiss. & Salsify & 20 & 1.5 & 0.3 & 0.3 & 3.1 & 0.7 & 1.2 & \\
\hline Cichorium intybus $\mathrm{L}$. & Chicory & 19 & 1.4 & 0.2 & 0.2 & 2.6 & 0.6 & 1.0 & \\
\hline Matricaria chamomilla $\mathrm{L}$. & Pineapple weed & 18 & 1.3 & 0.7 & 0.8 & 2.0 & 0.5 & 1.4 & \\
\hline Centaurea solstitialis L. & Yellow star-thistle & 11 & 0.8 & 0.2 & 0.2 & 2.4 & 0.6 & 0.9 & \\
\hline Silybum marianum (L.) Gaertner & Saint Mary's thistle & 8 & 0.6 & 0.2 & 0.2 & 1.2 & 0.3 & 0.5 & \\
\hline Sonchus oleraceus L. & Sow thistle & 7 & 0.5 & 0.3 & 0.3 & 1.7 & 0.4 & 0.8 & \\
\hline Senecio vulgaris L. & Groundsel & 1 & 0.1 & 0.1 & 0.1 & 0.1 & 0.1 & 0.1 & \\
\hline Conyza canadensis (L.) Cronquist & Horseweed & 6 & 0.4 & 0.2 & 0.2 & 1.0 & 0.2 & 0.5 & \\
\hline
\end{tabular}


International Journal of Scientific and Technological Research www.iiste.org ISSN 2422-8702 (Online), DOI: 10.7176/JSTR/6-01-05

Vol.6, No.01, 2020

Carduus pycnocephalus L.

$\begin{array}{llllllll}\text { Italian thistle } & 3 & 0.2 & 0.2 & 0.2 & 1.1 & 0.3 & 0.5 \\ \text { Veitch's blue } & 2 & 0.1 & 0.5 & 0.5 & 0.7 & 0.2 & 0.7 \\ \text { Hawk's beard } & 3 & 0.2 & 0.4 & 0.5 & 0.3 & 0.1 & 0.6 \\ \text { Prickly sow thistle } & 1 & 0.1 & 0.1 & 0.1 & 0.0 & 0.0 & 0.1\end{array}$

Echinops ritro L.

Crepis aspera $\mathrm{L}$

Sonchus asper (L.) Hill.

\section{BORAGINACEAE}

Buglossoides arvense (L.) Johnst.

$\begin{array}{llllllll}\text { Field gromwell } & 14 & 1.0 & 0.5 & 0.6 & 2.1 & 0.5 & 1.2\end{array}$

Anchusa azurea Miller.

Italian bugloss

$\begin{array}{lllllll}3 & 0.2 & 0.0 & 0.0 & 0.4 & 0.1 & 0.2\end{array}$

\section{BRASSICACEAE}

Sinapis arvensis L.

Charlock mustard

$\begin{array}{llllllll}81 & 5.9 & 9.6 & 11.6 & 41.3 & 10.0 & 22.2 & 1-5\end{array}$

Capsella bursa-pastoris (L.) Medik. Shepherd's purse

$\begin{array}{lllllll}53 & 3.9 & 3.6 & 4.3 & 27.7 & 6.7 & 11.5\end{array}$

Cardaria draba (L.) Desv.

Hoary cress

$\begin{array}{lllllll}12 & 0.9 & 0.2 & 0.3 & 2.4 & 0.6 & 0.9\end{array}$

Sisymbrium officinale (L.) Scop.

Hedge mustard

$\begin{array}{lllllll}7 & 0.5 & 0.2 & 0.2 & 0.9 & 0.2 & 0.5\end{array}$

Myagrum perfoliatum $\mathrm{L}$.

Bird's-eye cress

$\begin{array}{lllllll}6 & 0.4 & 0.2 & 0.2 & 0.7 & 0.2 & 0.4\end{array}$

Neslia paniculata (L.) Devs.

Descurainia sophia (L.) Webb

Ball mustard

$\begin{array}{lllllll}6 & 0.4 & 0.2 & 0.2 & 0.6 & 0.1 & 0.4\end{array}$

Thlaspi arvense $\mathrm{L}$.

Tansy mustard

$\begin{array}{lllllll}5 & 0.4 & 0.1 & 0.2 & 0.4 & 0.1 & 0.3\end{array}$

CARYOPHYLLACEAE

Field pennycress

$\begin{array}{lllllll}1 & 0.1 & 0.2 & 0.2 & 0.1 & 0.0 & 0.2\end{array}$

Agrostemma githago L.

Vaccaria pyramidata Medik

Silene conoidea $\mathrm{L}$.

Corn-cockle

Cowherb

Catchfly

Stellaria media (L.) Vill.

Chickweed

Spear Saltbush

$\begin{array}{lllllll}3 & 0.2 & 0.1 & 0.1 & 0.4 & 0.1 & 0.2\end{array}$

Atriplex patula L.

Field bindweed

$\begin{array}{lllllll}3 & 0.2 & 0.2 & 0.3 & 0.4 & 0.1 & 0.4\end{array}$

Convolvulus arvensis $\mathrm{L}$.

FABACEAE

Lens culinaris Medik

Vicia sativa $\mathrm{L}$.

Trifolium repens $\mathrm{L}$.

Lathyrus sativus L.

Melilotus officinalis (L.) Desr.

Medicago sativa $\mathrm{L}$.

Pisum sativum L.

Lentils

Garden vetch

$\begin{array}{lllllll}60 & 4.4 & 3.1 & 3.7 & 30.3 & 7.4 & 11.5\end{array}$

Glycyrrhiza glabra L.

GERANIACEAE

Geranium dissectum L.

Erodium hoefftianum C.A.Mey

White clover

Sweet pea

Sweetclover

Lucerne

Common pea

Liquorice plant

Cutleaf geranium

$21 \quad 1.5 \quad 1.2$

Stork's-bill

$\begin{array}{lllllll}11 & 0.8 & 0.2 & 0.2 & 1.8 & 0.4 & 0.7\end{array}$

\section{LAMIACEAE}

Lamium amplexicaule $\mathrm{L}$.

Henbit dead-nettle

$\begin{array}{lllllll}8 & 0.6 & 0.2 & 0.2 & 0.5 & 0.1 & 0.4\end{array}$

LILIACEAE

Muscari neglectum Guss.

Grape hyacinth

$\begin{array}{llll}4 & 0.3 & 0.1 & 0.1\end{array}$

$0.1 \quad 1$

$\begin{array}{ll}0.2 & 0.4\end{array}$ 
International Journal of Scientific and Technological Research www.iiste.org ISSN 2422-8702 (Online), DOI: 10.7176/JSTR/6-01-05

Vol.6, No.01, 2020

\begin{tabular}{|c|c|c|c|c|c|c|c|c|c|}
\hline Allium vineale $\mathrm{L}$. & Wild garlic & 3 & 0.2 & 0.1 & 0.1 & 0.8 & 0.2 & 0.3 & \\
\hline \multicolumn{10}{|l|}{ MALVACEAE } \\
\hline Malva neglecta Wallr. & Mallow & 7 & 0.5 & 0.2 & 0.2 & 0.6 & 0.1 & 0.4 & \\
\hline Alcea pallida Waldst. \& Kit. & Hollyhock & 2 & 0.1 & 0.0 & 0.0 & 0.1 & 0.0 & 0.1 & \\
\hline \multicolumn{10}{|l|}{ PAPAVERACEAE } \\
\hline Papaver rhoeas L. & Flanders poppy & 59 & 4.3 & 9.6 & 11.6 & 15.9 & 3.9 & 15.9 & \\
\hline \multicolumn{10}{|l|}{ PLANTAGINACEAE } \\
\hline Plantago lanceolata L. & Ribwort plantain & 1 & 0.1 & 0.1 & 0.1 & 0.1 & 0.0 & 0.1 & \\
\hline \multicolumn{10}{|l|}{ POACEAE } \\
\hline Avena sterilis $\mathrm{L}$. & Wild oat & 83 & 6.1 & 11.4 & 13.7 & 32.8 & 8.0 & 22.3 & $3-5$ \\
\hline Avena fatua $\mathrm{L}$. & Common wild oat & 55 & 4.0 & 4.3 & 5.2 & 17.2 & 4.2 & 9.8 & \\
\hline Hordeum murinum L. & False barley & 55 & 4.0 & 1.0 & 1.2 & 14.6 & 3.6 & 5.1 & \\
\hline Phalaris paradoxa $\mathrm{L}$. & Awned canary-grass & 48 & 3.5 & 1.7 & 2.0 & 12.1 & 2.9 & 5.3 & \\
\hline Poa trivialis $\mathrm{L}$. & Rough bluegrass & 45 & 3.3 & 1.0 & 1.2 & 10.5 & 2.6 & 4.1 & \\
\hline Alopecurus myosuroides Huds. & Blackgrass & 44 & 3.2 & 1.1 & 1.3 & 9.5 & 2.3 & 3.9 & -12 \\
\hline Bromus tectorum L. & Military grass & 17 & 1.2 & 0.9 & 1.1 & 2.0 & 0.5 & 1.7 & -40 \\
\hline Secale cereale $\mathrm{L}$. & Cereal rye & 15 & 1.1 & 0.2 & 0.3 & 1.9 & 0.4 & 0.8 & \\
\hline Lolium multiflorum Lam. & Italian ryegrass & 13 & 0.9 & 0.2 & 0.2 & 1.5 & 0.4 & 0.7 & $25-35$ \\
\hline Phragmites communis Trin. & Common reed & 6 & 0.4 & 0.2 & 0.2 & 0.8 & 0.2 & 0.4 & \\
\hline Phalaris brachystachys Link. & Canarygrass & 2 & 0.1 & 0.0 & 0.0 & 0.1 & 0.0 & 0.1 & \\
\hline Poa anпua L. & Bluegrass & 1 & 0.1 & 0.0 & 0.0 & 0.1 & 0.0 & 0.1 & \\
\hline
\end{tabular}

\section{POLYGONACEAE}

Polygonum convolvulus L.

Fallopia

Polygonum aviculare $\mathrm{L}$

Knotgrass

$\begin{array}{lllllll}8 & 0.6 & 0.2 & 0.2 & 0.2 & 0.0 & 0.3\end{array}$

Rumex crispus L.

Curled dock

$\begin{array}{lllllll}6 & 0.4 & 0.1 & 0.2 & 0.1 & 0.0 & 0.2\end{array}$

PRIMULACEAE

Anagallis arvensis $\mathrm{L}$.

Scarlet pimpernel

$\begin{array}{lllllll}1 & 0.1 & 0.1 & 0.1 & 0.1 & 0.0 & 0.1\end{array}$

RANUNCULACEAE

Ranunculus arvensis $\mathrm{L}$.

Adonis aestivalis L.

Pheasant's-eye

$\begin{array}{lllllll}77 & 5.6 & 4.3 & 5.2 & 24.4 & 5.9 & 11.7\end{array}$

RUBIACEAE

Galium aparine L.

Cleavers

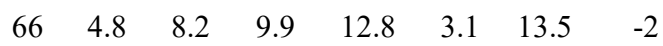

F: Frequency (\%), Fr: Relative Frequency (\%) D: Density (plant $\mathrm{m}^{-2}$ ), Dr: Relative Density (\%), A: Abundance (n), Ar: Relative Abundance (\%), IVI: Importance Value Index (\%), ET: Economic Threshold (plant $\mathrm{m}^{-2}$ )

A total of 40 weed species belonging to 20 different families including 1 monocot (12 species) and 19 dicot families (59 species) were collected from Siirt, Turkey. The Asteraceae was identified as the dominant family with 15 species, followed by Poaceae with 12, Brassicaceae and Fabaceae with 8's. Avena sterilis L. (83\%), Sinapis arvensis L. (81\%), Ranunculus arvensis L. (77\%), Galium aparine L. (66\%), and Cirsium arvense (L.) Scop. (61\%) species were the highest frequency values in wheat field of Siirt, Turkey. In the other hand, Avena sterilis L. (11.4 plant $\left.\mathrm{m}^{-2}\right)$, Sinapis arvensis L. and Papaver rhoeas L. (9.6 plant $\mathrm{m}^{-2}$ ), Galium aparine L. (8.2 plant $\mathrm{m}^{-2}$ ), and Cirsium arvense (L.) Scop. (5.5 plant $\mathrm{m}^{-2}$ ) species were the highest density. Also, Sinapis arvensis L. (41.3\%), Avena sterilis L. (32.8\%), Lens culinaris Medik. (30.3\%), Cirsium arvense (L.) Scop. (29.0\%), and Capsella bursa-pastoris (L.) Medik. 
$(27.7 \%)$ species were the highest abundance. The most important 10 weed species according to important value index determined in wheat fields of Siirt province were given in Figure 2.

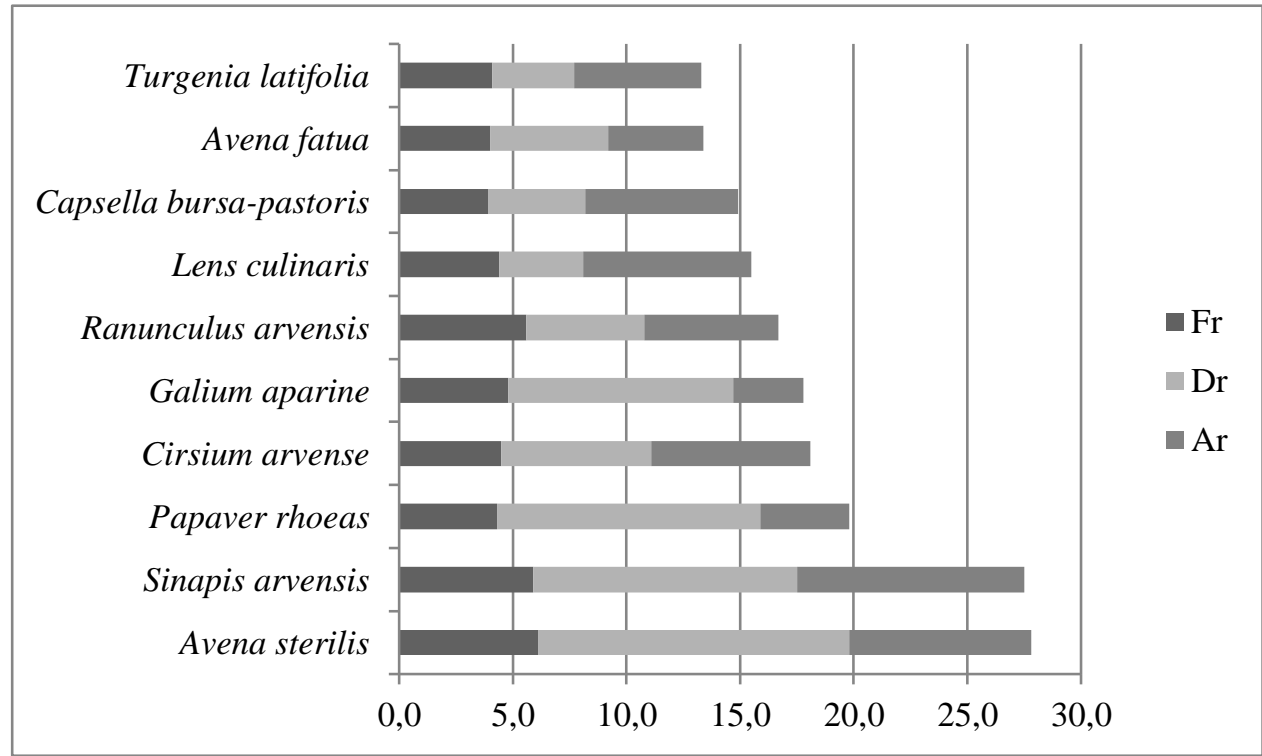

Figure 2. Weed species with highest importance value index (IVI, \%) in wheat fields of Siirt, Turkey

Species Avena sterilis L. (22.3\%), Sinapis arvensis L. (22.2\%), Papaver rhoeas L. (15.9\%), Cirsium arvense (L.) Scop. (14.1\%), and Galium aparine L. (13.5\%) were the highest importance value index in wheat field of Siirt, Turkey.

Some farmers interviewed stated that they applied wheat seeds pesticides before sowing to protect them from ground beetles (Zabrus sp.) and foot-rot disease (Fusarium spp.). In addition, participants reported surface spraying for un pest (Eurygaster integriceps) and septoria leaf blotch disease (Septoria tritici.). It was observed that pests were transported to the wheat fields in the spring. Many bugs were preferred weed hosts, and some were host specific. Migrations occurred in March-April, and insect populations were generally fed and developed through weeds near the fields (sometimes weeds in the fields). This period was consistent with weed survey dates and weeds and insects were identified as the main pests for wheat were recorded. Accordingly, Graminaceous weeds such as Bromus tectorum, Poa trivialis, Lolium multiflorum, and Hordeum murinum were found to host for Eurygaster integriceps, Zabrus sp., Anisoplia sp., and Pachytychius hordei pests.

\section{Discussion}

Similar to our findings (the predominant family was Asteraceae with 15 species), Ullah et al. (2016) found the predominant family Asteraceae (had 6 species). In addition to Brassicaceae, Poaceae, Polygonaceae and Caryophyllaceae families similar to the study, but Papilionaceae, Amaranthaceae, Chenopodiaceae and Plantaginaceae families were not found in Siirt province wheat fields. This situation revealed that the same family may be dominant in the wheat fields in different countries and only the number of different species having different families may vary.

The Asteraceae, Brassicaceae, and Poaceae families and Avena fatua, Sinapis arvensis, Galium aparine, and Papaver rhoeas species determined by Pala and Mennan (2018) were in parallel with the findings in this study. Consequently, the similarity of weed species in wheat and barley showed that weeds that are problematic in cereals may be similar.

Annual weeds, because of their high ability to proliferate because of the fastest colonization (Booth et al., 2003), especially annual and broadleaf weeds were identified as the most dense species in wheat fields of Siirt. Subedi (2013) identified Chenopodium album, Vicia sativa, Vicia hirsutum, Anagallis arvensis, Oxalis corniculata were major weeds in wheat field of Nepal on the basis of density and frequency. This shows that different weed species come to the fore in different climatic regions.

Khanal et al (2018) determined Anagallis arvensis was ranked first with the importance value index (IVI, \%) of 57.98 following Vicia sativa and Chenopodium album, disparately. The main reasons why IVI was different were climate, soil and applied farming methods. Tauseef et al, (2012.) found two 
important weeds including Cyperus rotundus L. and Echinochloa colona (L.) Link. were with the highest IVI of 20.9 and 17.3, respectively having the highest densities as well in the cotton fields. This situation showed that weed species that have problems in different cultivated plants and their IVI values may be different.

Cleavers and wild oats, followed by mayweeds, blackgrass, chickweed and poppy reported as the most competitive weeds in cereals by Finch et al. (2014), similarly, this study conducted in the province of Siirt was also identified. According to estimates of yield loss due to competition between weeds and wheat, the decision to chemical control depends on the economic threshold (Norris et al., 1999). Czapar et al. (1997) found found that $9 \%$ used economic thresholds as a basis for weed control. It is found that there is a lack of literature about the economic threshold of major weeds which are problematic especially in cereals, also in legumes, industrial plants, vegetables, fruits, and vineyards. Also, it were realized that there was a lack of literature about the weeds that host the bugs which are problematic in wheat field and their control and the possibilities of using biological control against weeds. In this study, it was founded on the frequency, density, abundance and importance indexes of weed species in the wheat fields of Siirt, Turkey, and identified their economic thresholds in the current literature. This research will shed light on the determination of the noxious weeds, economic threshold and environmentally-friendly integrated weed management tactics to be developed in wheat.

\section{Conclusions}

Weeds remain one of the most significant agronomic problems associated with wheat crop production. When evaluated of phytosociological parameters of weeds in wheat as a whole (frequency, density, abundance, economic threshold, and importance value index) Asteraceae with 15 species and Poaceae with 12 species were determined to be predominant families. The dominant weeds prevailing in wheat crops were wild oat (Avena sterilis L.) and charlock mustard (Sinapis arvensis L.) species. A. sterilis $(22.3 \%)$ was found to be the most important species of grass and $S$. arvensis $(22.2 \%)$ was the most important species of broadleaf weeds. Biology, ecology and economic threshold of these weeds should be taken into consideration when deciding the control method in wheat fields. Weeds have strong competition with the wheat crop for light, nutrients, moisture, and land which adversely affect the wheat production. Therefore, effective weed control is essential for realizing yield potential and minimizing weeds in wheat crops. The article contains common weeds found in wheat. The problem of weeds is very serious and is increasing rapidly. Since global warming, dams in the region, changing agricultural practices and plant protection methods cause the change of weed communities that are problematic in cereals and other agricultural products, especially wheat, it is important to carry out field surveys at regular intervals.

\section{Acknowledgements}

The research was funded by the Scientific Research Project Unit of Siirt University in Siirt, Turkey. The project number was 2018-SIÜZİR-047.

\section{References}

Ali, A., Streibig, J.C., Christensen, S. and Andreasen, C. (2012). Estimation of weed control threshold for an intelligent sprayer boom. In Information Technology, Automation and Precision Farming. International Conference of Agricultural Engineering-CIGR-AgEng 2012: Agriculture and Engineering for a Healthier Life, Valencia, Spain, 8-12 July 2012. CIGR-EurAgEng.

Ashiq, M., Muhammad, N. Ahmad, N. (2006). Comparative efficacy of different herbicides to control grassy weeds in wheat. Pak. J Weed Sci. Res., 12(3), 157-161.

Beer E., Heitefuss R. (1981): Determination of control thresholds and economic injury thresholds for monocotyledonous and dicotyledonous weeds in winter wheat and winter barley. II. Zeitschrift für Pflanzenkrankheiten und Pflanzenschutz, 88, 321-336. (In German).

Booth, B.D., Murphy, S.D. Swanton, C.J. (2003). Weed ecology in natural and agricultural systems. CABI Publishing, CAB International, Wallingford, UK. 
Boz, O., Uygur, F.N. (1997). Cukurova bölgesi bugday ekim alanlarindaki yabani hardal (Sinapis arvensis $\mathrm{L}$.) ve yabani figin (Vicia spp.) zarar seviyelerinin saptanmasi ve ekonomik zarar esiginin hesaplanmasi. Turkiye II. Herboloji Kongresi. 1-4 Eylül 1997-Izmir ve Ayvalik/Turkiye, 15-24.

Coble, H.D., Mortensen, D.A. (1992): The threshold concept and its application to weed science. Weed Technology, 6, 191-195.

Concenço, G., Tomazi, M., Correia, I.V.T., Santos, S.A., Galon, L. (2013). Phytosociological surveys: tools for weed science?. Planta Daninha, 31(2), 469-482.

Cousens, R, Wilson, B.J., Cussans, G.W. (1985). To spray or not to spray. The theory behind the practice. In Proceedings of the British Crop Protection Conference, 3, 671-678.

Cousens, R., Mortimer, M. (1995). Dynamics of Weed Populations. Cambridge, UK: Cambridge University Press.

Czapar, G.F., Curry, M.P., Wax, L.M. (1997). Grower acceptance of economic thresholds for weed management in Illinois. Weed Technology, 11(4), 828-831.

Davis, P.H. (1965-1989). Flora of Turkey and east Aegean islands., Edinburgh.

DIKA (2019). Tigris Development Agency. https://www.dika.org.tr/Last accessed 12.11.19

Finch, S., Samuel, A., Lane, G.P. (2014). Lockhart and wiseman's crop husbandry including grassland. Elsevier.

Gbèhounou, G. (2013). Guidance on Weed sssues and assessment of noxious weeds in a context of harmonized legislation for production of certified seeds. Plant Production and Protection Division, Food and Agriculture Organization of the United Nations.

Gerowitt, B., Heitefuss, R. (1990). Weed economic thresholds in cereals in the Federal Republic of Germany. Crop Protection, 9, 323-331.

Häusler, A., Nordmeyer, H., Niemann, P. (1998). Conditions for the site-specific weed management. Zeitschrift für Pflanzenkrankheiten und Pflanzenschutz, 16 (), 249-256. (In German).

Kadıglu, I., Ulug, E., Uremis, I., Uygur, F.N. Boz, O. (1993). Cukurova bugday ekim alanlarında gorulen yabani yulaf (Avena sterilis L.)'in ekonomik zarar esigi üzerinde araştırmalar. Türkiye I. Herboloji Kongresi, pp.3-5.

Khan, A., Ilyas, M. Hussain, T. (2005). Response of wheat to herbicides application and hand weeding under irrigated and nonirrigated conditions. Pak. J. Weed Sci. Res. 11(1/2), 1-9.

Khanal, S., Adhikari, S., Bhattarai, A., Shrestha, S. (2018). Diversity of weeds and population dynamics of predators and prey present in wheat-mustard ecosystem at Paklihawa, Rupandehi, Nepal. Journal of the Institute of Agriculture and Animal Science, 35(1), 173-181.

LeBaron, H.M., McFarland, J.E., Burnside, O.C. (2008). The triazine herbicides: a milestone in the development of weed control technology. In: H. M. LeBaron (eds) The triazine herbicides. Elsevier New York, NY pp.1-12.

Meiners, I. (2015). Management of black-grass (Alopecurus myosuroides Huds.) in winter wheat and taking into account the soil activity of post-emergence herbicides. 
Mennan, H., (2003). Economic thresholds of Sinapis arvensis (wild mustard) in winter wheat fields. Pakistan Journal of Agronomy (Pakistan).

MGM (2019). Meteorological Service https://www.mgm.gov.tr/Last accessed 05.10.19

Norris, R. F., \& Buhler, D. D. (1999). Ecological implications of using thresholds for weed management. Journal of crop production, 2, 31-58.

Odum E.P. (1971). Fundamentals of ecology. W. B. Saunders Company, Philadelphia, London, Toronto, $574 \mathrm{p}$

Oerke, E.C., (2006). Crop losses to pests: centenary review. J. Agric. Sci. 144, 31-43.

Onofri, A., Tei, F. (1994). Competitive ability and threshold levels of three broadleaf weed species in sunflower. Weed Research, 34(6), pp.471-479.

Pala, F., Mennan, H. (2017). Determination of weed species in wheat fields of Diyarbakir province. Plant Protection Bulletin, 57(4), 447-461.

Pala, F., Mennan, H. (2018). Major weeds in barley fields of Diyarbakir. $70^{\text {th }}$ International Symposium on Crop Protection, May 20, 20 p., Ghent, Belgium.

Pala, F., Mennan, H., Cig, F., Dilmen, H. (2018). Determination of weed seeds mixed with wheat product in Diyarbakir. Turkish Journal of Agricultural Research, 5(3), 183-190.

Peters, K., Breitsameter, L. Gerowitt, B. (2014). Impact of climate change on weeds in agriculture: a review. Agronomy for Sustainable Development, 34(4), 707-721.

Santos, W.F., Procopio, D.D.O., Silva, A.G., Fernandes, M.F., Barroso, A.L.L. (2016). Weed phytosociological and floristic survey in agricultural areas of Southwestern Goiás region. Planta Daninha, 34(1), 65-80.

Sartorato, I., Berti, A., Zanin, G. (1996). Estimation of economic thresholds for weed control in soybean (Glycine max (L.) Merr.). Crop Protection, 15(1), 63-68.

Spitters, C.J.T. (1989). Weeds: population dynamics, germination and competition. In Simulation and systems management in crop protection (pp. 182-216). Pudoc.

Subedi, H. (2013). Wheat weed identification and management under cereal production system Nepal. Journal of Sustainable Society, 2(3), 74-85.

Tauseef, M., Ihsan, F., Nazir, W., Farooq, J. (2012). Weed flora and importance value index (IVI) of the weeds in cotton crop fields in the region of Khanewal, Pakistan. Pakistan Journal of Weed Science Research, 18(3).

Travlos, I.S., Cheimona, N., Roussis, I. and Bilalis, D.J. (2018). Weed-species abundance and diversity indices in relation to tillage systems and fertilization. Frontiers in Environmental Science, 6, p.11.

TUIK (2018). Turkish Statistical Institute. http://www.tuik.gov.tr/Start.do Last accessed 21.12.18

Ullah, F., Ullah, A., Sohail, A. (2016). Medicinal and ecological diversity of weeds in wheat crop at Lower Dir, Pakistan. Pakistan Journal of Weed Science Research, 22(4). 
International Journal of Scientific and Technological Research

www.iiste.org ISSN 2422-8702 (Online), DOI: 10.7176/JSTR/6-01-05

Vol.6, No.01, 2020

Vazin, F. (2012). The Effects of Pigweed Redroot (Amaranthus retroflexus L.) Weed Competition and Its Economic Thresholds in Corn (Zea mays). Planta Daninha, 30(3), 477-485.

Wahmhof W., Heitefuss R. (1985). Investigations on the application of economic injury levels for weeds in winter barley. I: Factors of influence and possibilities of prognosis for the development of weed infestation. Zeitschrift für Pflanzenkrankheiten und Pflanzenschutz, 92, 1-16. (In German).

Zanin, G., Berti, A. Toniolo, L. (1993). Estimation of economic thresholds for weed control in winter wheat. Weed Research, 33(6), 459-467.

Zimdahl, R.L. (2013). Fundamentals of Weed Science, fourth ed. Academic Press. 